\title{
Laboratory diagnostics for Lyme disease
}

\author{
Lindsay $L^{1^{*}}$, Bernat $K^{1}$ and Dibernardo $A^{1}$ \\ National Microbiology Laboratory, Public Health Agency of Canada, Winnipeg, Manitoba \\ Corresponding author: robbin.lindsay@phac-aspc.gc.ca
}

\begin{abstract}
Background: Lyme disease is on the rise in Canada. It is a notifiable disease, and when infection is disseminated, serological testing provides supplemental evidence to confirm a case.

Objective: To describe the current diagnostic tests for Lyme disease, review the recommended approach to laboratory testing for Lyme disease and identify future research priorities for Lyme disease laboratory diagnostics in Canada.

Methods: A review of the literature was carried out. We then summarized parameters to consider before Lyme disease testing is conducted, described the current best practice to use a two-tiered diagnostic algorithm for the laboratory confirmation of disseminated Lyme disease, and analyzed the advantages and disadvantages of the supplemental tests for Lyme disease.

Results: Diagnostic testing is indicated in people who have symptoms of disseminated disease and a history of exposure to vector ticks. To maximize sensitivity and specificity, a two-tiered serological approach is recommended, consisting of an enzyme immunoassay (EIA) screening test followed by confirmation with Western blot (WB) testing. A number of other diagnostic tests are available; however, these are largely for research purposes.

Conclusion: Two-tiered serology is currently the best approach available to assist doctors when they are making a diagnosis of disseminated Lyme disease. The Public Health Agency of Canada (the Agency) will seek to improve on this approach through standardization of the Lyme disease diagnostics used across laboratories in Canada, evaluation of test performance characteristics of current and new diagnostic platforms and development of a process to secure robust serum panels to assist in the development and evaluation of new diagnostic tests for Lyme disease.
\end{abstract}

\section{Introduction}

Lyme disease (LD) is a tick-borne infection caused primarily by three species of spirochetes in the Borrelia burgdorferi sensu lato genogroup: $B$. burgdorferi sensu stricto (in North America and Western Europe), B. afzelii (in Western Europe, central Europe and Russia) and B. garinii (primarily in Europe, Russia and northern Asia) (1). The symptoms of Lyme disease occur in stages and involve a variety of tissues and organs, including the skin, joints, heart and nervous system (2). There has been a steady increase in the incidence of Lyme disease in parts of central and eastern Canada (3-5) due to the recent range expansion of the primary tick vector, Ixodes scapularis (6).

Lyme disease has been a nationally notifiable disease since 2009 (7). The objective of this article is to describe the current diagnostic tests for Lyme disease, including a review of the recommended approaches to laboratory testing, and identify future research priorities for Lyme disease diagnostics in Canada.

\section{Methods}

An extensive review of peer-reviewed literature was carried out. We then summarized the key parameters to consider before Lyme disease testing is conducted, described the current best practice of a two-tiered serological algorithm for the laboratory confirmation of disseminated Lyme disease and explored the advantages 
and disadvantages of the supplemental tests. We also outlined future research plans to be undertaken by the Agency's National Microbiology Laboratory.

\section{Results}

\section{Considerations prior to testing}

Early localized Lyme disease does not require diagnostic testing before antibiotic therapy is started. A presumptive diagnosis can be made on the basis of the clinical presentation and a credible history of exposure to infected blacklegged ticks (8). Typically, diagnostic testing is appropriate for people with a history of tick exposure and symptoms of disseminated Lyme disease infection, since test sensitivity improves as the bacteria affect tissue systems other than the skin $(8,9)$. Testing, however, should be limited to those with objective signs of infection $(10,11)$.

The following information is required prior to testing:

- Detailed travel history and date of onset of symptoms - This information should be included on the laboratory requisition, as it helps the diagnostic laboratory apply the most appropriate test platform. For example, there are different tests to identify Lyme disease acquired in Europe/Asia versus North America (12), and different tests are used for early infections versus infections that may have been present for some time (13).

- A history of antibiotic treatment - This can dampen the immune response to infection and may complicate the interpretation of serological tests (14).

- Other infections or pre-existing conditions - Infection with other related pathogens (e.g. syphilis) and autoimmune disorders may cause false-positive results (15).

- Prior history of laboratory-confirmed Lyme disease-This is important, as there is no pattern of serological response that can differentiate re-infection from an initial infection with $B$. burgdorferi (16).

\section{Testing for Lyme disease}

Although there are several testing strategies that can assist in making a diagnosis of Lyme disease (Table 1), serology is currently the only standardized laboratory testing available. The following describes the different test platforms used for the laboratory diagnosis of Lyme disease. The advantages and limitations of each are presented in Table 2.

Table 1: Laboratory testing approaches for Lyme disease (9)

\begin{tabular}{|c|c|c|}
\hline Stage of infection & $\begin{array}{l}\text { Recommended testing } \\
\text { strategy* }^{*}\end{array}$ & Specimen type \\
\hline $\begin{array}{l}\text { Erythema migrans, acute phase } \\
\text { (seasonal occurrence and exposure in an } \\
\text { endemic area**) }\end{array}$ & Clinical diagnosis and empirical treatment & None \\
\hline $\begin{array}{l}\text { Erythema migrans, acute phase } \\
\text { (out of season or no known exposure in an } \\
\text { endemic area) }\end{array}$ & $\begin{array}{l}\text { 2-tiered serology }{ }^{\dagger} \text { - repeat EIA in four weeks } \\
\text { if negative; treatment at physician's } \\
\text { discretion NAAT, isolation }\end{array}$ & $\begin{array}{l}\text { Serum } \\
\text { Biopsy, plasma }\end{array}$ \\
\hline \multirow{2}{*}{$\begin{array}{l}\text { Characteristic neurological, cardiac or joint } \\
\text { involvement }\end{array}$} & 2-tiered serology ${ }^{\dagger}$ & Serum \\
\hline & NAAT & $\begin{array}{l}\text { Synovial or } \\
\text { cerebrospinal fluid }\end{array}$ \\
\hline $\begin{array}{l}\text { Persistent symptoms following recommended } \\
\text { treatment }\end{array}$ & None & None \\
\hline
\end{tabular}

\footnotetext{
* Tests, such as nucleic acid amplification test (NAAT) or bacterial isolation, are not frequently requested or performed.

** Endemic areas are localities where blacklegged ticks are established and $B$. burgdorferi cycles of transmission are

maintained.

+ Enzyme immunoassay (EIA) followed, where appropriate, by confirmatory Western blots using diagnostic kits licensed in Canada.
} 


\section{Serology testing}

The Canadian Public Health Laboratory Network recommends a two-tiered approach to Lyme disease testing, consisting of a sensitive enzyme immunoassay (EIA) followed, if positive or equivocal, by a specific Western blot test (9). The rationale for this approach is that the overall sensitivity and specificity are maximized when these tests are performed in sequence.

The immune response to $B$. burgdorferi infection begins with the appearance of IgM antibodies, usually within two weeks of a tick bite (17). These antibodies may persist for months or even years despite effective antimicrobial therapy (18). Following that $\operatorname{lgM}$ response, $\lg G$ antibodies develop in most patients, typically after one month of infection (9).

Serology provides a snapshot of the immune status of the patient at the time of the specimen collection. For instance, if Lyme disease is suspected on the basis of symptoms but early serological testing is negative; followup testing on a convalescent sample is recommended (9). The two most commonly performed serological tests are detailed below.

\section{Enzyme immunoassay (EIA)}

An enzyme immunoassay is used as a screening test to detect $\lg M$ and/or $\lg G$ antibodies in serum that are directed against the bacterium that causes LYME DISEASE. Commercial kits, such as an enzyme-linked immunosorbent assay, rely on the use of whole-cell preparations of $B$. burgdorferi (1) and/or recombinant antigens (19) (e.g. C6 peptide). The format of the assay allows the simultaneous screening of a relatively large number of samples. While most enzyme immunoassays are highly sensitive, they may lack specificity (i.e. false positives can occur as a result of other medical conditions).

\section{Western blot (WB)}

The Western blot test is used as the corroborative test, and it has greater specificity than the enzyme immunoassay $(11,20)$. It detects antibodies in serum that are directed against electrophoretically separated antigen extracts and recombinant antigens native to $B$. burgdorferi (21). Commercial kits are used to test for antibodies to individual genospecies of Borrelia (12) and to differentiate $\operatorname{lgM}$ from IgG antibodies. A positive Western blot result is required to confirm exposure to $B$. burgdorferi (22), and seroconversion from $\lg M$ to $\lg G$ Western blot antibodies provides definitive evidence of a recent infection (9).

Table 2: Laboratory tests for Lyme disease and their advantages and limitations

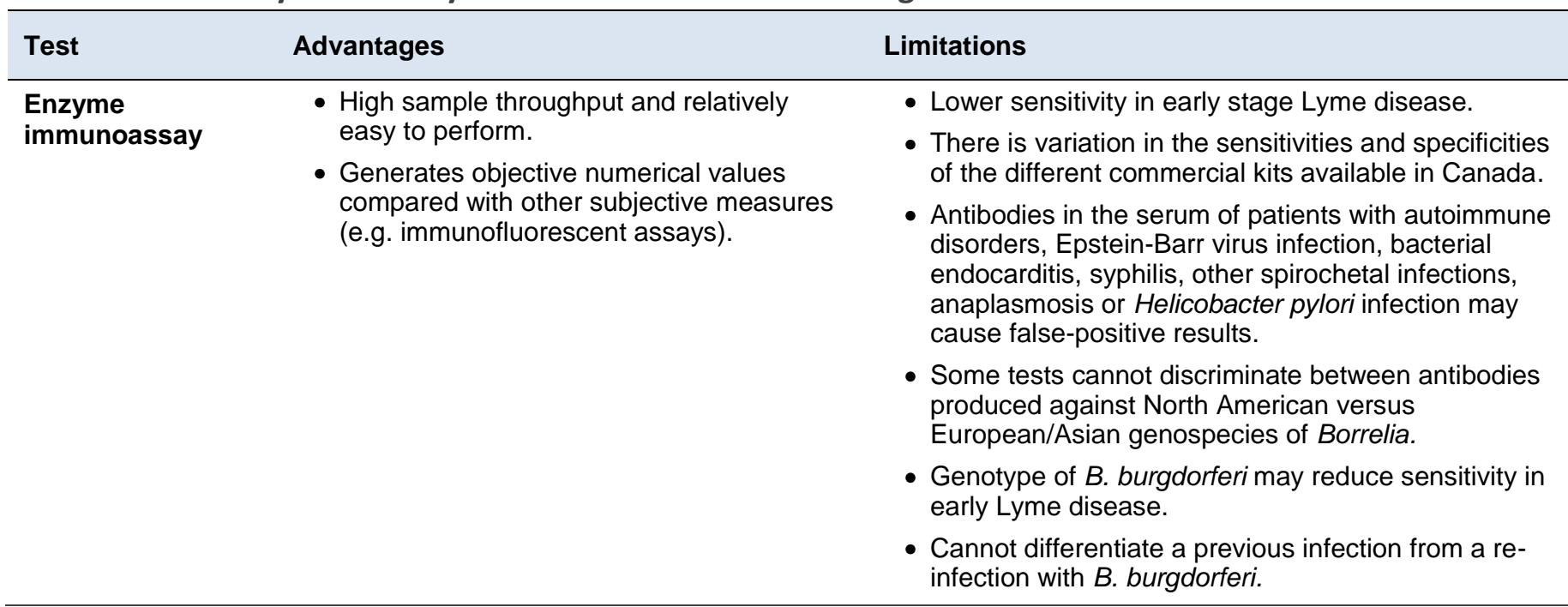




\begin{tabular}{|c|c|c|}
\hline Test & Advantages & Limitations \\
\hline Western blot & $\begin{array}{l}\text { - High specificity such that these tests can } \\
\text { be used to rule out other etiologic agents. } \\
\text { - Able to determine reactive immunoglobulin } \\
\text { classes (lgG vs. IgM) and help differentiate } \\
\text { early from longer-standing infections. }\end{array}$ & $\begin{array}{l}\text { - Interpretation of results is subjective (e.g. scoring } \\
\text { band position and intensity) for Western blot assays } \\
\text { that do not use an automated reader. } \\
\text { - Significant cross-reactivity occurs among European } \\
\text { genospecies. } \\
\text { - LgM antibodies are inherently cross-reactive, which } \\
\text { may lead to false-positive results. } \\
\text { - False-negative lgG Western blot results may occur } \\
\text { early in the course of infection or as a result of } \\
\text { antibiotic treatment. }\end{array}$ \\
\hline \multicolumn{3}{|c|}{ SUPPLEMENTAL LABORATORY TESTS (Not routinely performed) } \\
\hline Bacterial isolation & $\begin{array}{l}\text { - Highly specific and could be useful for } \\
\text { determining infecting genotypes of } \\
\text { B. burgdorferi. }\end{array}$ & $\begin{array}{l}\text { Collection of specimens can be invasive. } \\
\text { Relatively low sensitivity, expensive, labour-intensive } \\
\text { and long incubation period required for results. }\end{array}$ \\
\hline $\begin{array}{l}\text { Nucleic acid } \\
\text { amplification } \\
\text { testing (NAT) }\end{array}$ & $\begin{array}{l}\text { - Able to detect } B \text {. burgdorferi DNA after } \\
\text { antibiotic treatment has started, therefore } \\
\text { able to distinguish an ongoing infection } \\
\text { from persistent symptoms due to an } \\
\text { immunologic mechanism. } \\
\text { - Borrelia DNA can be detected in EM } \\
\text { lesions before the appearance of serum } \\
\text { antibodies and without the delay } \\
\text { associated with bacterial isolation. }\end{array}$ & $\begin{array}{l}\text { - Poor sensitivity due to low bacterial load in some } \\
\text { clinical samples. } \\
\text { - Lack of standardization with respect to target genes. }\end{array}$ \\
\hline
\end{tabular}

\section{Two-tiered algorithm for the laboratory diagnosis of Lyme disease}

The two-tiered approach to testing is illustrated in Figure 1. The first tier involves the use of an EIA. If this EIA test is negative, WB testing is not indicated. If symptoms persist, the EIA test can be repeated on a convalescent sample collected 3-6 weeks later. If the EIA is positive or equivocal, the second tier or corroborative Western blot assay is performed. In early infections (i.e. symptoms for less than six weeks), both the $\lg M$ and $\lg G$ Western blot tests are performed; however, if the patient has had symptoms for more than six weeks, only the IgG Western blot assay is performed.

\section{Figure1. Two-tiered serological testing for Lyme disease}

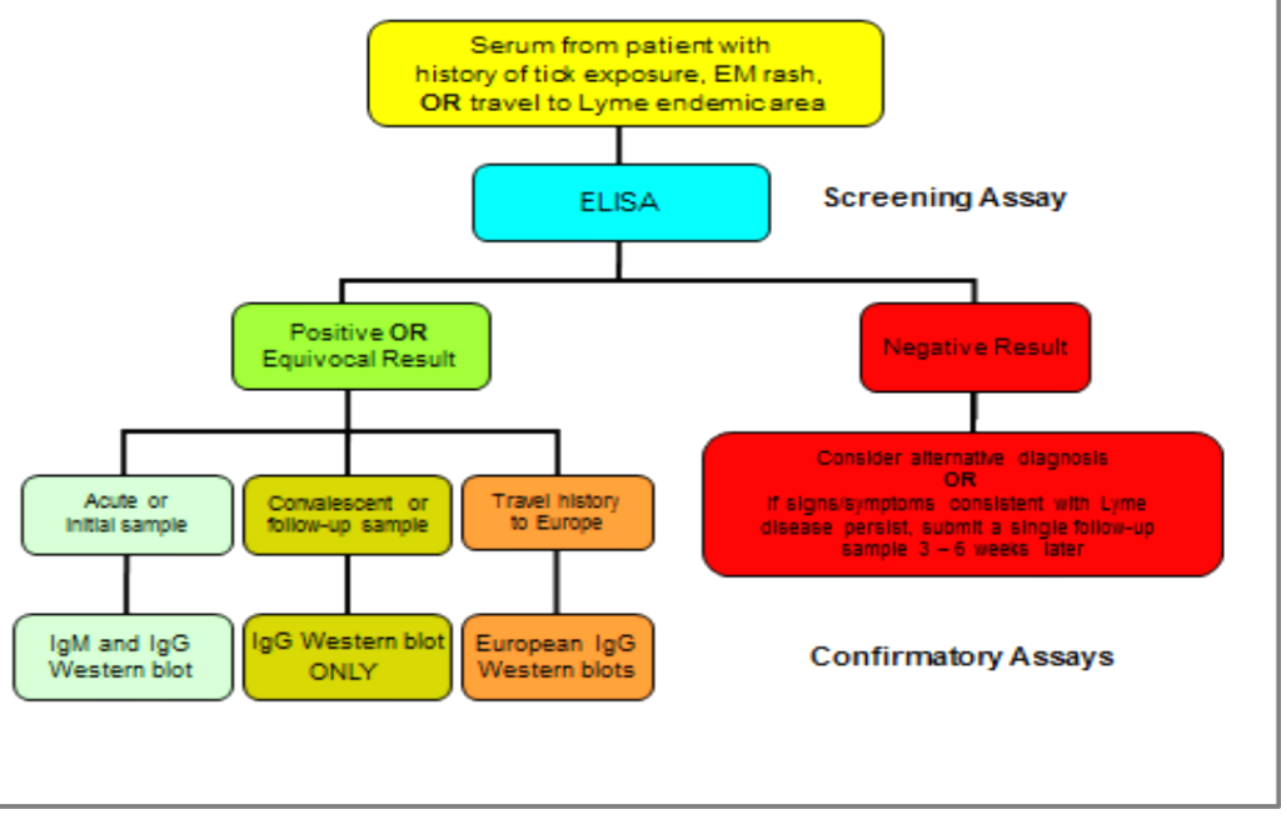


The final result of serological testing is considered positive only when the EIA is reactive (positive or equivocal) and the WB is also positive (Table 3). This two-tiered system maximizes the sensitivity and specificity of the assays and increases the likelihood of observing a seroconversion (from lgM to $\lg G$ ) that is evident in most bona fide $B$. burgdorferi infections $(1,17,21,23)$.

Table 3: Interpretation of Western blot results (in conjunction with an equivocal or positive EIA)

\begin{tabular}{ll}
\hline Western blot result & Interpretation \\
\hline Both IgM and IgG Western blots negative & $\begin{array}{l}\text { Result not consistent with a B. burgdorferi infection; however, if } \\
\text { symptoms persist submit a follow-up sample 3-6 weeks later. }\end{array}$
\end{tabular}

Only lgM Western blot positive*

Potentially a false-positive result if this is NOT an acute case (i.e. $<6$ weeks post onset of symptoms).

Only lgG Western blot positive**

Result consistent with an infection with B. burgdorferi of greater than 4 weeks' duration.

Both IgM and IgG Western blots positive

Result indicates recent or previous infection with $B$. burgdorferi.

${ }_{* *}$ IgM positive WB -2 of 3 significant bands present.

IgG positive WB -5 of 10 significant bands present (22).

\section{Supplemental laboratory tests to detect B. burgdorferi}

\section{Bacterial isolation}

The recovery of viable $B$. burgdorferi from clinical specimens is accomplished by incubating the sample in specialized culture medium. Although this test remains the "gold standard" for diagnosis of Lyme disease(7), the procedure is expensive to perform, lacks clinical sensitivity and is prone to contamination (24). The greatest practical limitation is that cultures can require up to eight weeks of incubation because of the small number of viable organisms present in many specimen types (17). These factors reduce the clinical applications of this test and restrict its use to research studies (9).

\section{Nucleic acid amplification testing (NAAT)}

Nucleic acid amplification testing (NAAT) has been used to decrease turnaround times for Lyme disease diagnostic results $(25,26)$. Several formats of polymerase chain reaction (PCR) testing (i.e. nested, real-time or quantitative) are used to amplify a variety of Borrelia-specific genetic targets in clinical specimens (27). Positive results are most frequently seen in the early phase of the disease (28). The sensitivity of polymerase chain reaction on cerebrospinal fluid (CSF) is low or variable and therefore of limited usefulness in evaluating patients with neurological signs $(1,21)$. Although these assays can identify an infection sooner than serological testing $(25,27)$, their use is restricted to research studies at the present time $(8,9)$.

\section{Challenges associated with diagnostic testing for Lyme disease}

Physicians and laboratory scientists have concerns regarding results reported by some private laboratories that are inconsistent with results obtained by Canadian public health laboratories. A number of private laboratories may not be using sufficiently validated tests or interpretation criteria. The use of assays that do not have adequately established accuracy and have not been sufficiently validated may result in the reporting of falsepositive results.

Some of these tests include capture assays for antigens in urine, immunofluorescence staining, cell sorting of cell wall-deficient or cystic forms of $B$. burgdorferi, lymphocyte transformation tests (29) and a new culture method for serum (30).

Currently, not following the two-tiered algorithm (e.g. by performing a Western blot alone or after the EIA is negative) can increase the frequency of false-positive results. This in turn could lead to possible misdiagnosis and unnecessary treatment (1). Clinicians should have an understanding of the current common misconceptions 
about LYME DISEASE(31) and know the best laboratory practices to diagnose it (1); this would facilitate informed discussions with patients who have questions and concerns.

\section{Future developments}

As mentioned, there are a wide variety of diagnostic tests available to assist in the diagnosis of Lyme disease $(21,32)$, and considerable debate exists concerning the accuracy and reliability of some of these tests (32-34). At this time there is no single laboratory test that is $100 \%$ sensitive and specific for the confirmation of Lyme disease. This is further complicated by the fact that not all individuals who are infected with $B$. burgdorferi present in the same way. Improvements in diagnostic test platforms are a priority. The search for "biomarkers" of Lyme disease that do not rely on serological response is ongoing (35). Variations of the two-tiered approach, which typically reduce or eliminate the use of WBs, are being evaluated (36-39) and may help simplify test interpretation and improve sensitivity in early Lyme disease.

One of the biggest challenges to evaluating new diagnostic approaches (40) in Canada is the lack of serum panels or a collection of well-characterized samples from individuals with confirmed $B$. burgdorferi infection. It is also imperative that we gain a full understanding of the genotypes of $B$. burgdorferi that are infecting Canadians (41) and establish whether the diagnostic tests currently in use can detect all of them with comparable sensitivity.

The Agency's National Microbiology Laboratory plans to work with diagnostic laboratories across Canada to review current Lyme disease diagnostic practices and quality assurance systems, and to evaluate the need for enhanced internal and external proficiency testing. In the longer term, the Agency also plans to 1) review and update the existing laboratory guidelines for Lyme disease, 2) determine and compare test performance characteristics of all EIA and Western blot platforms currently in use in Canada, 3) evaluate "new" diagnostic platforms on a high priority and ongoing basis and 4) initiate the process of development of a robust serum panel for use in evaluation of new assays (42). This work will advance quality diagnostic testing for Lyme disease in Canada.

\section{Conclusion}

The incidence of Lyme disease is increasing in Canada. In persons with erythema migrans rash and a reliable history of exposure to blacklegged ticks, testing is not required and treatment can be started empirically. The clinical assessment of patients in the disseminated phases of Lyme disease can be further supported by laboratory testing.

At this time, there is no perfect laboratory test for Lyme disease; however, the two-tiered serological approach provides the most sensitive and specific results to date. Improper use of serologic tests or the use of diagnostic tests or interpretative criteria that have not been fully validated may lead to misdiagnosis and unnecessary antibiotic treatment. Future efforts will focus on standardization of testing, and the development and evaluation of new diagnostic approaches to optimize the detection of Lyme disease.

\section{Acknowledgements}

We would like to thank our colleagues in the provincial diagnostic laboratories and hospital laboratories across Canada who provided important and useful feedback on the laboratory diagnostic testing for Lyme disease that is performed at the National Microbiology Laboratory.

\section{Conflict of interest}

The authors have no conflicts of interest to declare. 


\section{References}

(1) Johnson BJB, Aguero-RosenfeLyme diseaseME, Wilske B. Sood SK, editor. Lyme borreliosis in Europe and North America: epidemiology and clinical practice. [Internet]. Hoboken, NJ: John Wiley \& Sons, Inc.; 2011Serodiagnosis of Lyme borreliosis ; p. 185-212.cited 28 November 2013]. DOI: 10.1002/9780470933961.ch10

(2) Hatchette TF, Davis I, Johnston BL. Lyme disease: clinical diagnosis and treatment. CCDR. 2014;40-11:194208.

(3) Ogden NH, Lindsay LR, Morshed M, Sockett PN, Artsob H. The emergence of Lyme disease in Canada. CMAJ [Internet]. 2009 [cited 28 November 2013];180(12):1221-4.

(4) Ogden NH, Artsob H, Lindsay LR, Sockett PN. Lyme disease: A zoonotic disease of increasing importance to Canadians. Can Fam Phys [Internet]. 2008;54(10):1381-4.

(5) Ogden NH, Lindsay LR, Morshed M, Sockett PN, Artsob H. The rising challenge of Lyme borreliosis in Canada. CCDR [Internet]. 2008;34(1):1-19.

(6) Ogden NH, Koffi JK, Pelcat Y, Lindsay LR. Environmental risk from Lyme disease in centeral and eastern Canada: a summary of recent surveillance information. CCDR. 2014;40-5:74-82.

(7) Case definitions for communicable diseases under national surveillance - 2009. CCDR [Internet]. 2009 November 2009;35(Suppl 2):1-123.

(8) Wormser GP, Dattwyler RJ, Shapiro ED, Halperin JJ, Steere AC, Klempner MS, Krause PJ, Bakken JS, Strle F, Stanek G, Bockenstedt L, Fish D, Dumler JS, Nadelman RB. The clinical assessments treatment, and prevention of Lyme disease, human granulocytic anaplasmosis, and babesiosis: Clinical practice guidelines by the Infectious Diseases Society of America. Clin Infect Dis [Internet]. 2006;43(9):1089-134.

(9) Canadian Public Health Laboratory Network. The laboratory diagnosis of Lyme borreliosis: Guidelines from the Canadian Public Health Laboratory Network. Can J Infect Dis Med Microbiol [Internet]. 2007 Mar;18(2):145-8.

(10) Seltzer EG, Shapiro ED. Misdiagnosis of Lyme disease: When not to order serologic tests. Pediatr Infect Dis J [Internet]. 1996;15(9):762-3.

(11) Tugwell P, Dennis DT, Weinstein A, Wells G, Shea B, Nichol G, Hayward R, Lightfoot R, Baker P, Steere AC. Laboratory evaluation in the diagnosis of Lyme disease. Ann Intern Med [Internet]. 1997 Dec 15;127(12):1109-23.

(12) Branda JA, Strle F, Strle K, Sikand N, Ferraro MJ, Steere AC. Performance of United States serologic assays in the diagnosis of Lyme borreliosis acquired in Europe. Clin Infect Dis [Internet]. 2013 Aug;57(3):333-40.

(13) Schoen RT. Better laboratory testing for Lyme disease: No more Western blot. Clin Infect Dis [Internet]. 2013 [cited 27 November 2013];57(3):341-3.

(14) Aguero-Rosenfelyme diseaseME, Nowakowski J, Bittker S, Cooper D, Nadelman RB, Wormser GP. Evolution of the serologic response to Borrelia burgdorferi in treated patients with culture-confirmed erythema migrans. J Clin Microbiol [Internet]. 1996;34(1):1-9.

(15) Johnson BJ, Robbins KE, Bailey RE, Cao BL, Sviat SL, Craven RB, Mayer LW, Dennis DT. Serodiagnosis of Lyme disease: accuracy of a two-step approach using a flagella-based ELISA and immunoblotting. J Infect Dis [Internet]. 1996 Aug;174(2):346-53.

(16) Nadelman RB, Wormser GP. Reinfection in patients with Lyme disease. Clin Infect Dis [Internet]. 2007 Oct 15;45(8):1032-8. 
(17) Aguero-Rosenfelyme diseaseME, Wang G, Schwartz I, Wormser GP. Diagnosis of Lyme borreliosis. Clin Microbiol Rev [Internet]. 2005 Jul;18(3):484-509.

(18) Kalish RA, McHugh G, Granquist J, Shea B, Ruthazer R, Steere AC. Persistence of immunoglobulin M or immunoglobulin $\mathrm{G}$ antibody responses to Borrelia burgdorferi $10-20$ years after active Lyme disease. Clin Infect Dis [Internet]. 2001;33(6):780-5.

(19) Liang FT, Alvarez AL, Gu Y, Nowling JM, Ramamoorthy R, Philipp MT. An immunodominant conserved region within the variable domain of VIsE, the variable surface antigen of Borrelia burgdorferi. J Immunol [Internet]. 1999;163(10):5566-73.

(20) Dressler F, Whalen JA, Reinhardt BN, Steere AC. Western blotting in the serodiagnosis of Lyme disease. J Infect Dis [Internet]. 1993 Feb;167(2):392-400.

(21) Aguero-RosenfeLyme diseaseME. Lyme disease: laboratory issues. Infect Dis Clin North Am [Internet]. 2008 [cited 27 November 2013];22(2):301-13.

(22) Centers for Disease Control and Prevention (CDC). Recommendations for test performance and interpretation from the Second National Conference on Serologic Diagnosis of Lyme disease. MMWR Morb Mortal Wkly Rep [Internet]. 1995 Aug 11;44(31):590-1.

(23) Craven RB, Quan TJ, Bailey RE, Dattwyler R, Ryan RW, Sigal LH, Steere AC, Sullivan B, Johnson BJ, Dennis DT, Gubler DJ. Improved serodiagnostic testing for Lyme disease: results of a multicenter serologic evaluation. Emerg Infect Dis [Internet]. 1996 Apr-Jun;2(2):136-40.

(24) Nowakowski J, Schwartz I, Liveris D, Wang G, Aguero-RosenfeLyme diseaseME, Girao G, McKenna D, Nadelman RB, Cavaliere LF, Wormser GP, Lyme diseaseStudy Group. Laboratory diagnostic techniques for patients with early Lyme diseaseassociated with erythema migrans: a comparison of different techniques. Clin Infect Dis [Internet]. 2001 Dec 15;33(12):2023-7.

(25) Wormser GP, Wang G. Sood SK, editor. Lyme borreliosis in Europe and North America : epidemiology and clinical practice. [Internet]. Hoboken, N.J.: John Wiley \& Sons, Inc.; 2011The role of culture and nucleic acid amplification in diagnosis of Lyme borreliosis ; p. 159-83.. DOI: 10.1002/9780470933961.ch9

(26) Dumler JS. Molecular diagnosis of Lyme disease: review and meta-analysis. Mol Diagn [Internet]. 2001 Mar;6(1):1-11.

(27) Eshoo MW, Schutzer SE, Crowder CD, Carolan HE, Ecker DJ. Achieving molecular diagnostics for Lyme disease. Expert Rev Mol Diagn [Internet]. 2013 Nov;13(8):875-83.

(28) Liveris D, Schwartz I, McKenna D, Nowakowski J, Nadelman R, Demarco J, lyer R, Bittker S, Cooper D, Holmgren D, Wormser GP. Comparison of five diagnostic modalities for direct detection of Borrelia burgdorferi in patients with early Lyme disease. Diagn Microbiol Infect Dis [Internet]. 2012 Jul;73(3):243-5.

(29) Centers for Disease Control and Prevention (CDC). Caution regarding testing for Lyme disease. Morb Mortal Wkly Rep [Internet]. 2005;54(5):125.

(30) Johnson BJ, Pilgard MA, Russell TM. Assessment of New Culture Method to Detect Borrelia species in Serum of Lyme diseasePatients. J Clin Microbiol [Internet]. 2013 Aug 14

(31) Halperin JJ, Baker P, Wormser GP. Common misconceptions about Lyme disease. Am J Med [Internet]. 2013 [cited 28 November 2013];126(3):264.e1,264.e7.

(32) Johnson BJB. Halperin JJ, editor. Lyme disease: An Evidence-based Approach. Cambridge, MA, USA: CABI Publishing; 2011 Laboratory diagnostic testing for Borrelia burgdorferi infection ; p. 73-88.;

(33) Bowie WR. Guidelines for the management of Lyme disease: The controversy and the quandary. Drugs [Internet]. 2007;67(18):2661-6. 
(34) Halperin JJ, Baker P, Wormser GP. Halperin JJ, editor. Lyme disease: An Evidence-based Approach. Cambridge, MA, USA: CABI Publishing; 2011Lyme disease: the Great Controversy ; p. 259-70.

(35) Cerar T, Ogrinc K, Lotric-Furlan S, Kobal J, Levicnik-Stezinar S, Strle F, Ruzic-Sabljic E. Diagnostic value of cytokines and chemokines in Lyme neuroborreliosis. Clin Vaccine Immunol [Internet]. 2013 Oct;20(10):1578-84.

(36) Porwancher RB, Hagerty CG, Fan J, Landsberg L, Johnson BJB, Kopnitsky M, Steere AC, Kulas K, Wong SJ. Multiplex immunoassay for Lyme disease using VIsE1-IgG and pepC10-IgM antibodies: Improving test performance through bioinformatics. Clin Vaccine Immunol [Internet]. 2011;18(5):851-9.

(37) Wormser GP, Schriefer M, Aguero-Rosenfe ME, Levin A, Steere AC, Nadelman RB, Nowakowski J, Marques A, Johnson BJB, Dumler JS. Single-tier testing with the C6 peptide ELISA kit compared with two-tier testing for Lyme disease. Diagn Microbiol Infect Dis [Internet]. 2013;75(1):9-15.

(38) Branda JA, Linskey K, Kim YA, Steere AC, Ferraro MJ. Two-tiered antibody testing for Lyme diseasewith use of 2 enzyme immunoassays, a whole-cell sonicate enzyme immunoassay followed by a vlse $c 6$ peptide enzyme immunoassay. Clin Infect Dis [Internet]. 2011;53(6):541-7.

(39) Branda JA, Aguero-RosenfeLyme diseaseME, Ferraro MJ, Johnson BJB, Wormser GP, Steere AC. 2-Tiered antibody testing for early and late Lyme disease using only an immunoglobulin $\mathrm{G}$ blot with the addition of a VIsE band as the second-tier test. Clin Infect Dis [Internet]. 2010;50(1):20-6.

(40) Steere AC, McHugh G, Damle N, Sikand VK. Prospective study of serologic tests for Lyme disease. Clin Infect Dis [Internet]. 2008 [cited 27 November 2013];47(2):188-95.

(41) Ogden NH, Margos G, Aanensen DM, Drebot MA, Feil EJ, Hanincová K, Schwartz I, Tyler S, Lindsay LR. Investigation of genotypes of Borrelia burgdorferi in Ixodes scapularis ticks collected during surveillance in Canada. Appl Environ Microbiol [Internet]. 2011;77(10):3244-54.

(42) Aguero-RosenfeLyme diseaseME. Committee on Lyme diseaseand Other Tick-Borne Diseases: The State of the Science, Institute of Medicine., editors. Critical needs and gaps in understanding prevention, amelioration, and resolution of Lyme and other tick-borne diseases [electronic resource] : the short-term and long-term outcomes : workshop report. [Internet]. Washington, DC: National Academies Press; 2011Diagnostics for Lyme disease: Knowledge gaps and needs ; p. 125-30. 